medRxiv preprint doi: https://doi.org/10.1101/2021.05.05.21256710; this version posted May 11, 2021. The copyright holder for this preprint (which was not certified by peer review) is the author/funder, who has granted medRxiv a license to display the preprint in perpetuity. All rights reserved. No reuse allowed without permission.

\title{
Evolution of COVID-19 symptoms during the first 9 months after illness onset
}

\section{Authors:}

Elke Wynberg ${ }^{1,2}\left(\right.$ MBBS MSc) $^{*}$, Hugo van Willigen ${ }^{2,3}(M D)^{*}$, Maartje Dijkstra $^{1,2}(M D)$, Anders Boyd ${ }^{1,4}$ (PhD), Neeltje A. Kootstra $(P h D)$, Joost G. van den Aardweg ${ }^{5}$ (MD PhD), Marit J. van Gils ${ }^{3}(P h D)$, Amy Matser ${ }^{1}(\mathrm{PhD})$, Marije R. de Wit ${ }^{1}(\mathrm{MD})$, Tjalling Leenstra ${ }^{1}$ (MD PhD), Godelieve de Bree ${ }^{2}$ (MD PhD $)^{\star *}$, Menno D. de Jong ${ }^{3}(\mathrm{MD} P h D)^{* *}$, Maria Prins ${ }^{1,2}(\mathrm{PhD})^{\star *}$ and the RECoVERED Study Group ${ }^{\star * *}$

\section{Affiliations:}

${ }^{1}$ Department of Infectious Diseases, Public Health Service of Amsterdam, Amsterdam, the Netherlands

${ }^{2}$ Department of Infectious Diseases, Amsterdam UMC, University of Amsterdam, Amsterdam Institute for Infection and Immunity, Amsterdam, the Netherlands

${ }^{3}$ Department of Medical Microbiology \& Infection Prevention, Amsterdam UMC, University of Amsterdam, Amsterdam Institute for Infection and Immunity, Amsterdam, the Netherlands

${ }^{4}$ Stichting HIV Monitoring, Amsterdam, the Netherlands

5 Department of Pulmonology, Amsterdam UMC, University of Amsterdam, Amsterdam, the Netherlands

${ }^{6}$ Department of Experimental Immunology, Amsterdam UMC, University of Amsterdam, Amsterdam Institute for Infection and Immunity, Amsterdam, the Netherlands

* Joint first author ** Joint last author ${ }^{* * *}$ Listed at the end of the article 
medRxiv preprint doi: https://doi.org/10.1101/2021.05.05.21256710; this version posted May 11, 2021. The copyright holder for this preprint (which was not certified by peer review) is the author/funder, who has granted medRxiv a license to display the preprint in perpetuity.

All rights reserved. No reuse allowed without permission.

Evolution of COVID-19 symptoms during the first 9 months after illness onset

Manuscript

Contributions: EW, GdB, TL, MdJ and MP contributed to the conceptualization. EW, HwW, MD, NK, JvdA, and MvG contributed to the data collection, data curation and project administration. GdB, MD, MdJ, MP, HvW, secured study financing and medical ethical approval. EW and AB conducted the formal analysis and data visualisation. EW, TL and MP drafted the initial manuscript. All authors read a draft of the manuscript and provided feedback, contributed to interpretation of the data, and approved the final manuscript.

\section{Corresponding author:}

Elke Wynberg

Email: ewijnberg@ggd.amsterdam.nl

\section{Acknowledgements:}

The authors wish to thank all RECoVERED study participants. Additionally we to thank Daniëla van Santen for helping to create the transition plots.

\section{Key words:}

COVID-19, symptoms, recovery 
medRxiv preprint doi: https://doi.org/10.1101/2021.05.05.21256710; this version posted May 11,2021 . The copyright holder for this preprint (which was not certified by peer review) is the author/funder, who has granted medRxiv a license to display the preprint in perpetuity. All rights reserved. No reuse allowed without permission.

Evolution of COVID-19 symptoms during the first 9 months after illness onset

Manuscript

\section{Abstract}

\section{Background}

Few longitudinal data on COVID-19 symptoms across the full spectrum of disease severity are available. We evaluated symptom onset, severity and recovery up to nine months after illness onset.

\section{Methods}

The RECoVERED Study is a prospective cohort study based in Amsterdam, the Netherlands. Participants aged>18 years were recruited following SARS-CoV-2 diagnosis via the local Public Health Service and from hospitals. Standardised symptom questionnaires were completed at recruitment, at one week and month after recruitment, and monthly thereafter. Clinical severity was defined according to WHO criteria. Kaplan-Meier methods were used to compare time from illness onset to symptom recovery, by clinical severity. We examined determinants of time to recovery using multivariable Cox proportional hazards models.

\section{Results}

Between 11 May 2020 and 31 January 2021, 301 COVID-19 patients (167[55\%] male) were recruited, of whom 99/301(32.9\%) had mild, 140/301(46.5\%) moderate, 30/301(10.0\%) severe and $32 / 301(10.6 \%)$ critical disease. The proportion of symptomatic participants who reported at least one persistent symptom at 12 weeks after illness onset was greater in those with severe/critical disease $(81.7 \%[95 \% \mathrm{Cl}=68.7-89.7 \%])$ compared to those with mild or moderate disease (33.0\%[95\% $\mathrm{Cl}=23.0-43.3 \%]$ and $63.8 \%[95 \% \mathrm{Cl}=54.8-71.5 \%])$. Even at nine months after illness onset, almost half of all participants $(42.1 \%[95 \% \mathrm{Cl}=35.6-48.5])$ overall continued to report $\geq 1$ symptom. Recovery was slower in participants with $\mathrm{BMI} \geq 30 \mathrm{~kg} / \mathrm{m}^{2}(\mathrm{HR} 0.51[95 \% \mathrm{Cl}=0.30-0.87])$ compared to those with $\mathrm{BMl}<25 \mathrm{~kg} / \mathrm{m}^{2}$, after adjusting for age, sex and number of comorbidities.

\section{Conclusions}

COVID-19 symptoms persisted for nine months after illness onset, even in those with mild disease. Obesity was the most important determinant of speed of recovery from symptoms. 
medRxiv preprint doi: https://doi.org/10.1101/2021.05.05.21256710; this version posted May 11, 2021. The copyright holder for this preprint (which was not certified by peer review) is the author/funder, who has granted medRxiv a license to display the preprint in perpetuity. All rights reserved. No reuse allowed without permission.

Evolution of COVID-19 symptoms during the first 9 months after illness onset

Manuscript

\section{Introduction}

The clinical spectrum of coronavirus disease 2019 (COVID-19), caused by severe acute respiratory syndrome coronavirus 2 (SARS-CoV-2), ranges from asymptomatic presentation to fatal illness. Although the acute symptomatology of hospitalised patients has been well documented[1-4], less is known about the symptomatology of milder cases. In addition, robust longitudinal data on the longterm persistence of symptoms and factors that may affect recovery are scarce.

A growing body of evidence suggests that post-COVID syndrome (i.e. long COVID or Post-Acute Sequelae of SARS-CoV-2 infection [PASC]) may negatively affect both individual quality of life and the economic productivity of society [5-7]. A recent cross-sectional study from Wuhan, China, for example, reported that the vast majority (76\%) of previously hospitalised patients still suffered from at least one symptom, most commonly fatigue, six months after symptom onset[7].

The RECoVERED study is a prospective cohort study of individuals with SARS-CoV-2 infection across the full spectrum of disease severity. We evaluated the incidence, severity and duration of symptoms in participants with mild, moderate, severe and critical COVID-19, and examined determinants of time to recovery from symptoms. 
medRxiv preprint doi: https://doi.org/10.1101/2021.05.05.21256710; this version posted May 11, 2021. The copyright holder for this preprint (which was not certified by peer review) is the author/funder, who has granted medRxiv a license to display the preprint in perpetuity. All rights reserved. No reuse allowed without permission.

Evolution of COVID-19 symptoms during the first 9 months after illness onset

Manuscript

\section{Methods}

\section{Study design and participants}

The RECoVERED study is an ongoing cohort study of individuals with laboratory-confirmed SARSCoV-2 infection in Amsterdam, the Netherlands. The study aims to describe the immunological, clinical and psychosocial sequelae of SARS-CoV-2 infection. Recruitment of study participants began on 11 May 2020. Non-hospitalised participants were identified from notification data at the Public Health Service of Amsterdam (PHSA) and approached by telephone up to 7 days after SARS-CoV-2 diagnosis. Prospectively-enrolled hospitalised participants were approached on the COVID-19 wards of two hospitals in Amsterdam. A limited number of hospitalised patients were enrolled retrospectively until 30 June 2020 up to 3 months following SARS-CoV-2 diagnosis. For the present analyses we included all participants with a follow-up of at least one month by 28 February 2021.

Eligibility criteria included laboratory confirmation of SARS-CoV-2 infection by PCR, antigen testing or serology; aged 16-85 years and adequate understanding of Dutch or English. Patients residing in a nursing home prior to SARS-CoV-2 infection and those with mental disorders that would interfere with adherence to study procedures were excluded.

The RECOVERED study was approved by the medical ethical review board of the Amsterdam University Medical Centre (NL73759.018.20). All participants provided written informed consent. 
medRxiv preprint doi: https://doi.org/10.1101/2021.05.05.21256710; this version posted May 11, 2021. The copyright holder for this preprint (which was not certified by peer review) is the author/funder, who has granted medRxiv a license to display the preprint in perpetuity. All rights reserved. No reuse allowed without permission.

Evolution of COVID-19 symptoms during the first 9 months after illness onset

Manuscript

\section{Study procedures}

At enrolment and at day 7 and month 1 of follow-up, a standardised questionnaire (based on the World Health Organisation Case Report Form [8]) on the presence, start and stop dates, and severity of 18 symptoms was completed by interviewing the participant (Figure S1). Participants subsequently completed monthly questionnaires on the presence of symptoms.

Biological specimens were collected at each monthly study visit (Figure S1). Heart rate, respiratory rate $(\mathrm{RR})$ and oxygen saturation $\left(\mathrm{SpO}_{2}\right)$ were measured at enrolment and at day 7 of follow-up, or retrieved from hospital records for retrospectively-enrolled participants. Past medical history and socio-demographic data were collected during the first month of follow-up, and data on COVID-19related complications, treatment, and investigations were collected at month 1 of follow-up and threemonthly from month 3. Self-reported data were verified with hospital electronic medical records when available.

\section{Definitions}

Illness onset was the first day on which symptoms were experienced; for asymptomatic patients, this was defined as the date of SARS-CoV-2 diagnosis. Complete recovery was defined as resolution of all COVID-19 symptoms. As per National Institute for Health and Care Excellence (NICE) guidelines[9], the acute phase of disease was defined as the first 4 weeks after illness onset, and post-COVID syndrome as symptoms persisting at least 12 weeks after illness onset.

Clinical severity groups were defined based on WHO COVID-19 disease severity criteria[10]. Mild disease was defined as having a $\mathrm{RR}<20 / \mathrm{min}$ and $\mathrm{SpO}_{2}>94 \%$ on room air at both enrolment and day 7 study visits; moderate disease as having a RR20-30/min, $\mathrm{SpO}_{2}$ 90-94\% and/or receiving oxygen therapy at enrolment or day 7 study visits; severe disease as having a $\mathrm{RR}>30 / \mathrm{min}$ or $\mathrm{SpO}_{2}<90 \%$ at enrolment or day 7 study visits; critical disease as requiring ICU admission as a result of COVID-19 at any point. 
medRxiv preprint doi: https://doi.org/10.1101/2021.05.05.21256710; this version posted May 11, 2021. The copyright holder for this preprint (which was not certified by peer review) is the author/funder, who has granted medRxiv a license to display the preprint in perpetuity.

All rights reserved. No reuse allowed without permission.

Evolution of COVID-19 symptoms during the first 9 months after illness onset

Manuscript

Symptom severity was measured on a four-point scale, with the exception of dyspnoea, measured using the 6-point modified Medical Research Council (mMRC) breathlessness scale[11]. Comorbidities at illness onset were those listed by the WHO as associated with severe COVID-19[12]: cardiovascular disease (CVD), diabetes mellitus (DM), chronic lung disease (CLD), severe liver disease, chronic kidney disease, immunodeficiency, cancer and/or cerebrovascular disease. Obesity was excluded from the comorbidity variable because body mass index (BMI) was defined separately, categorised in $\mathrm{kg} / \mathrm{m}^{2}$ as: $<25$, underweight or normal weight; $25-30$, overweight; $>30$, obese. Ethnicity was based on the participant and their parents' country of birth [13].

Loss to follow-up (LTFU) was defined as active withdrawal from the study or two consecutive no-show appointments despite 3 attempts to establish contact. Date of LTFU was defined as the date of last contact with the participant.

\section{Statistical analyses}

Socio-demographic and clinical characteristics of participants were compared between clinical severity groups.

The incidence proportions for 18 different symptoms at illness onset and one and four weeks after illness onset were calculated as the number of participants reporting each symptom over the total number of participants in follow-up at that point, and was compared by clinical severity group. Asymptomatic participants contributed to the denominator. Given the potential recall bias in reporting symptom onset, we restricted this analysis to prospectively-enrolled participants. For symptoms reported by $>20 \%$ of participants at 12 weeks in any severity group (the most persistent symptoms), changes in self-reported symptom severity over time during the acute phase were visualised using alluvial plots, both overall and by clinical severity group.

The proportion of participants with ongoing symptoms (firstly, with at least one symptom and secondly, for each symptom separately) were estimated using Kaplan-Meier survival curves and compared by severity group using the log-rank test. The at-risk period began at illness onset and continued until symptom recovery, loss to follow up, 9 months after illness onset, or last study visit prior to 28 
medRxiv preprint doi: https://doi.org/10.1101/2021.05.05.21256710; this version posted May 11, 2021. The copyright holder for this preprint (which was not certified by peer review) is the author/funder, who has granted medRxiv a license to display the preprint in perpetuity.

All rights reserved. No reuse allowed without permission.

Evolution of COVID-19 symptoms during the first 9 months after illness onset

Manuscript

February 2021 (i.e. administrative censor date), whichever occurred first. Asymptomatic participants were excluded from all symptom survival analysis.

We assessed the effect of age, sex, BMI, and number of comorbidities at illness onset on time to complete recovery from symptoms using univariable and multivariable Cox proportional hazards models in which these four variables were included. Interactions between BMI and the other variables were assessed. Clinical severity was not included in the multivariable model due to collinearity with the other variables. Two sensitivity analyses were performed to explore the impact of recall bias: firstly, restricting the analysis to prospectively-enrolled participants and secondly, left-truncating participants at the date of study entry (ignoring any recovery event occurring prior to enrolment).

A $p<0.05$ was considered statistically significant. Statistical analyses were performed using Stata (StataCorp LLC, v.15.1) and R (RStudio, v.1.2.5033). 
medRxiv preprint doi: https://doi.org/10.1101/2021.05.05.21256710; this version posted May 11, 2021. The copyright holder for this preprint (which was not certified by peer review) is the author/funder, who has granted medRxiv a license to display the preprint in perpetuity. All rights reserved. No reuse allowed without permission.

Evolution of COVID-19 symptoms during the first 9 months after illness onset

Manuscript

\section{Results}

\section{Study population}

Between 11 May 2020 and 31 January 2021, 301 participants were enrolled, of whom the majority $(210 / 301 ; 70.0 \%)$ prospectively. Of these 301 participants, 99 (33\%) experienced mild, 140 (46\%) moderate, $30(10 \%)$ severe and $32(11 \%)$ critical disease (Table 1). Participants with severe or critical disease were older than those with mild or moderate disease $(p<0.001)$ and had higher BMI $(p=0.006)$. CVD, CLD, DM and immunosuppression were significantly more common among participants with severe or critical COVID-19 compared to those with mild or moderate disease (Table 1). Median time from illness onset to recruitment was 8 days (IQR=5-12) for prospectively enrolled and 85 days $(\mathrm{IQR}=73-94)$ for retrospectively enrolled participants. Until 28 February 2021, 42 participants were lost to follow-up. One death, due to COVID-19, occurred during follow-up.

\section{Incidence proportions and severity of symptoms during the acute phase of infection}

During the acute phase of infection, fatigue and cough were the most frequently reported symptoms (Table 2). The incidence proportion for fatigue and cough as well as for fever, myalgia, loss of appetite, diarrhoea, and nausea (part of the WHO COVID-19 case definition[14]) did not differ between clinical severity groups during the acute phase (Table 2). By four weeks after illness onset, the incidence proportion for dyspnoea was higher in participants with moderate and severe/critical disease $(65 \%$ and $67 \%$, respectively; severe and critical participants combined due to small numbers) compared to participants with mild disease (43\%). Within the first week after illness onset, a significantly greater proportion of patients with mild and moderate COVID-19 reported loss of smell and/or taste, headache, rhinorrhoea and sore throat compared to the severe/critical COVID-19 group and, with the exception of sore throat, this difference remained at one month after illness onset.

Transition plots showed that while most participants transitioned to a lower level of severity over time across the five persistent symptoms (fatigue, cough, dyspnoea, loss of smell and/or taste and myalgia), some transitioned to a higher severity level over time (Figure 1). Among those with mild 
medRxiv preprint doi: https://doi.org/10.1101/2021.05.05.21256710; this version posted May 11, 2021. The copyright holder for this preprint (which was not certified by peer review) is the author/funder, who has granted medRxiv a license to display the preprint in perpetuity. All rights reserved. No reuse allowed without permission.

Evolution of COVID-19 symptoms during the first 9 months after illness onset

Manuscript

disease, the majority of participants reported loss of smell and/or taste as severe at baseline, although most reported improvement within the first week of follow-up (Figures S2a-e).

\section{Time to recovery from symptoms}

Time to complete recovery was longer in symptomatic participants with moderate and severe/critical disease than in those with mild COVID-19 (log-rank $p<0.001$; Figure 2). At least one ongoing symptom was reported at 12 weeks after illness onset, by $33.0 \%(95 \% \mathrm{Cl}=23.0 \%-43.3 \%)$ of participants with mild, $63.9 \%(95 \% \mathrm{Cl}=54.8-71.6 \%)$ with moderate and $81.7 \%(95 \% \mathrm{Cl}=68.7-89.7 \%)$ with severe/critical disease. Among participants with mild disease, median time to complete recovery was 57 days (Figure 2), although $20.3 \%(95 \% \mathrm{Cl}=11.4-30.9 \%)$ continued to report at least one ongoing symptom at nine months after illness onset. Among participants with moderate and severe/critical disease, more than half reported at least one ongoing symptom at nine months after illness onset (53.0\%[95\% $\mathrm{Cl}=43.2-61.8 \%]$ and $52.9 \%[95 \% \mathrm{Cl}=38.1-65.6 \%]$, respectively). Supplementary Figures 3a-e show Kaplan-Meier survival curves for the individual 18 symptoms, by clinical severity group.

\section{Determinants of time to recovery from symptoms}

$\mathrm{BMI}$ at illness onset showed the strongest association with time to complete recovery in multivariable analyses: obese participants had a $46 \%($ aHR $0.54,95 \% \mathrm{Cl}=0.32-0.90])$ and overweight participants a $23 \%$ slower recovery (aHR $0.77,95 \% \mathrm{Cl}=0.52-1.14])$ compared to those of normal weight $(p=0.046)$ (Figure 3). No statistically significant interactions were identified between BMI and the other covariates. Results were comparable in both sensitivity analyses (Figures S4a-b).

In multivariable analysis of time to recovery from each of the five most persistent symptoms (Table S1a-e), being obese at illness onset was associated with slower recovery from cough (aHR 0.56 , $95 \% \mathrm{Cl}=0.35-0.89)$ and loss of smell and/or taste $(\mathrm{aHR} 0.44,95 \% \mathrm{Cl}=0.25-0.76)$. Increased age was associated with slower recovery from cough (aHR $0.81,95 \% \mathrm{Cl}=0.72-0.92)$, dyspnoea (aHR 0.82 , $95 \% \mathrm{Cl}=0.70-0.96$ ), and myalgia (aHR $0.74,95 \% \mathrm{Cl}=0.65-0.85)$. Number of comorbidities at illness onset was only associated with recovery from fatigue, where those with one comorbidity recovered more than twice as slowly as those without comorbidities (aHR $0.45,95 \% \mathrm{Cl}=0.28-0.72$ ). When we 
medRxiv preprint doi: https://doi.org/10.1101/2021.05.05.21256710; this version posted May 11, 2021. The copyright holder for this preprint (which was not certified by peer review) is the author/funder, who has granted medRxiv a license to display the preprint in perpetuity.

All rights reserved. No reuse allowed without permission.

Evolution of COVID-19 symptoms during the first 9 months after illness onset

Manuscript

replaced number of comorbidities with the presence of each of CVD, CLD, DM or immunodeficiency in the multivariable models for each of these symptoms, no statistically significant effect on time to recovery was detected for any of these specific comorbidities. 
medRxiv preprint doi: https://doi.org/10.1101/2021.05.05.21256710; this version posted May 11, 2021. The copyright holder for this preprint (which was not certified by peer review) is the author/funder, who has granted medRxiv a license to display the preprint in perpetuity.

All rights reserved. No reuse allowed without permission.

Evolution of COVID-19 symptoms during the first 9 months after illness onset

Manuscript

\section{Discussion}

To our knowledge, this study is the first to report detailed longitudinal data on the evolution of COVID-

19 symptoms in a cohort of individuals with mild to critical disease. We observed that the incidence of certain hallmark COVID-19 symptoms were comparable between clinical severity groups during the acute phase of illness. Despite an overall improvement in severity of the most persistent COVID19 symptoms during the first month of illness, one-third of the mild group, nearly two-thirds of the moderate group and more than four-fifths of patients with severe/critical disease met NICE criteria for post-COVID syndrome. Even at nine months after illness onset, one-fifth of those with mild disease and over half of participants with either moderate or severe/critical disease experienced at least one ongoing symptom. Obesity at illness onset was the strongest determinant of slow recovery from symptoms.

Since the start of the COVID-19 pandemic, avoiding the immediate consequences of hospitalisation and mortality has been the primary goal. Longer term sequelae of COVID-19 have received relatively little attention, especially among non-hospitalised patients. In our study, the proportion of participants reporting fatigue, fever and cough during the first month of illness were as high in mild COVID-19 patients as they were in moderate, severe or critical patients. Although time to recovery from symptoms was shorter in those with mild disease, as many as one in three participants with mild COVID-19 still reported symptoms 12 weeks after illness onset. Indeed, the proportion of participants meeting the NICE definition of post-COVID syndrome in our cohort ( $57.8 \%$ overall) was comparable to other prospective cohort studies[15, 16], but higher than estimates by the UK Office for National Statistics and among healthcare workers [17, 18]. Although this could be partly explained by the fact that we limited our analysis to symptomatic participants, the consequences of these proportions when extrapolated to a global level may be substantial. As new viral variants and challenges in vaccination programmes worldwide continue to hinder effective control measures, the number of people with postCOVID syndrome will only continue to increase. 
medRxiv preprint doi: https://doi.org/10.1101/2021.05.05.21256710; this version posted May 11, 2021. The copyright holder for this preprint (which was not certified by peer review) is the author/funder, who has granted medRxiv a license to display the preprint in perpetuity.

All rights reserved. No reuse allowed without permission.

Evolution of COVID-19 symptoms during the first 9 months after illness onset

Manuscript

Although patient advocacy groups have helped in making post-COVID syndrome a research priority[19], studies to date have differed in study population, follow-up time and symptoms evaluated [9], making it difficult to synthesize all available evidence. Moreover, the symptom profiles that falls under post-COVID syndrome are diverse [20], resulting in a heterogenous patient group requiring different management strategies. A universally accepted and evidence-based definition of postCOVID syndrome is key to comparing findings across studies and settings, and to develop syndromespecific interventions. Moreover, an validated risk score for post-COVID syndrome could help prevention and identification of those requiring support. Our study, for example, suggests that obese individuals, regardless of sex, age and number of comorbidities at illness onset, may benefit from early intervention. In addition to its independent effect on recovery, obesity is associated with having a lower socio-economic status and reduced access to health and care services[21], both of which may also be associated with a slower recovery from symptoms. Over and above the impact of on acute COVID-19 hospitalisation and mortality [4, 22], reducing the prevalence of obesity may also help reduce the future burden of post-COVID syndrome.

Fatigue was the most commonly reported symptom both during the acute phase and at 12 weeks from illness onset, including among individuals with mild or moderate disease. Previous analyses have estimated that the societal impact of fatigue can be significant, due to both direct healthcare costs and indirect financial losses resulting from reduced economic productivity[23]. As those with mild COVID-19 represent the majority of COVID-19 cases worldwide in terms of absolute numbers, developing strategies to prevent, diagnose and manage post-COVID fatigue should be an urgent research priority. Among participants with moderate and severe/critical disease, dyspnoea and myalgia additionally persisted beyond 12 weeks in a large proportion of participants. Similar results have been reported in other settings: previously-hospitalised COVID-19 patients in Wuhan, China still had abnormal chest imaging findings and pulmonary diffusing capacity at 6 months after illness onset [7], whilst a cross-sectional study of hospitalised COVID-19 patients in the UK reported that the majority of participants reported myalgia at a median follow-up of 16 weeks after discharge from hospital[24]. In our multivariable analysis, older age was the most important determinant of slower 
medRxiv preprint doi: https://doi.org/10.1101/2021.05.05.21256710; this version posted May 11, 2021. The copyright holder for this preprint (which was not certified by peer review) is the author/funder, who has granted medRxiv a license to display the preprint in perpetuity.

All rights reserved. No reuse allowed without permission.

Evolution of COVID-19 symptoms during the first 9 months after illness onset

Manuscript

time to recovery from both of these symptoms. Exploring the underlying mechanism as to why these symptoms persist in older patients may help identify interventions that could be beneficial in the recovery process.

This study has several strengths. Frequent symptom questionnaires collected longitudinally since illness onset allowed the natural progression of COVID-19 symptoms to be described to a level of detail not previously reported. We were able to enrol patients with mild symptoms (underrepresented in other studies) as well as those who were critically ill, so that the full spectrum of COVID-19 disease could be represented. Several limitations must be recognised. Survival bias among the retrospectively-enrolled hospitalised participants may have caused an underestimation of time to complete recovery in those with severe/critical disease, although results were comparable when restricting our analyses to prospectively identified participants. Questionnaires in languages other than Dutch and English were not offered, therefore individuals with a migration background, who have been disproportionally affected by COVID-19, also in Amsterdam[25, 26], were underrepresented in this cohort. Furthermore, misclassification bias may have resulted from using ICU admission as a proxy for critical disease; suitability for ICU admission is also judged by the patient's chance of survival; indeed, those with critical disease tended to be younger and have a lower BMI than those in the severe group. Finally, the natural progression of disease may differ between SARS-CoV-2 variants[27] and treatments received. Therefore, our results may not be representative for future patients infected with SARS-CoV-2, especially as the treatment landscape for COVID-19 changes and new variants continue to arise.

We demonstrated that post-COVID syndrome is common, even after mild disease. Symptoms persisted for nine months after illness onset in one-fifth of participants with mild disease and in more than half of participants with moderate and severe/critical disease. Obesity was the most important predictor of slow recovery and thus creating an environment which facilitates healthy living behaviours is of utmost importance, even during a pandemic. Next steps in post-COVID syndrome research must include assessing the public health and socioeconomic impact, identifying further predictive and 
medRxiv preprint doi: https://doi.org/10.1101/2021.05.05.21256710; this version posted May 11, 2021. The copyright holder for this preprint (which was not certified by peer review) is the author/funder, who has granted medRxiv a license to display the preprint in perpetuity.

All rights reserved. No reuse allowed without permission.

Evolution of COVID-19 symptoms during the first 9 months after illness onset

Manuscript

prognostic characteristics, and exploring the underlying biological mechanisms of disease in order to identify and develop effective interventions. 
medRxiv preprint doi: https://doi.org/10.1101/2021.05.05.21256710; this version posted May 11, 2021. The copyright holder for this preprint (which was not certified by peer review) is the author/funder, who has granted medRxiv a license to display the preprint in perpetuity.

All rights reserved. No reuse allowed without permission.

Evolution of COVID-19 symptoms during the first 9 months after illness onset

Manuscript

\section{RECoVERED Study Group:}

Public Health Service of Amsterdam: Ivette Agard, Jane Ayal, Floor Cavder, Marianne Craanen, Udi Davidovich, Annemarieke Deuring, Annelies van Dijk, Ertan Ersan, Laura del Grande, Joost Hartman, Nelleke Koedoet, Romy Lebbink, Dominique Loomans, Agata Makowska, Tom du Maine, Ilja de Man, Lizenka van der Meij, Marleen van Polanen, Maria Oud, Clark Reid, Leeann Storey, Marc van Wijk Amsterdam University Medical Centres: Joyce van Assem, Marijne van Beek, Eric Moll van Charante, Orlane Figaroa, Leah Frenkel, Xiaochuan (Alvin) Han, Agnes Harskamp-Holwerda, Mette Hazenberg, Soemeja Hidad, Nina de Jong, Hans Knoop, Lara Kuijt, Anja Lok, Pythia Nieuwkerk, Colin Russell, Karlijn van der Straten, Annelou van der Veen, Bas Verkaik, Anouk Verveen, Gerben-Rienk Visser 
medRxiv preprint doi: https://doi.org/10.1101/2021.05.05.21256710; this version posted May 11, 2021. The copyright holder for this preprint (which was not certified by peer review) is the author/funder, who has granted medRxiv a license to display the preprint in perpetuity. All rights reserved. No reuse allowed without permission.

Evolution of COVID-19 symptoms during the first 9 months after illness onset

Manuscript

\section{References}

1. Wiersinga, W.J., et al., Pathophysiology, Transmission, Diagnosis, and Treatment of Coronavirus Disease 2019 (COVID-19): A Review. JAMA, 2020. 324(8): p. 782-793.

2. Guan, W.-j., et al., Clinical Characteristics of Coronavirus Disease 2019 in China. New England Journal of Medicine, 2020. 382(18): p. 1708-1720.

3. Chen, T., et al., Clinical characteristics of 113 deceased patients with coronavirus disease 2019: retrospective study. (1756-1833 (Electronic)).

4. Huang, C., et al., Clinical features of patients infected with 2019 novel coronavirus in Wuhan, China. The Lancet, 2020. 395(10223): p. 497-506.

5. Calvo-Bonacho, E., et al., COVID-19 and Sick Leave: An Analysis of the Ibermutua Cohort of Over 1,651,305 Spanish Workers in the First Trimester of 2020. (2296-2565 (Print)).

6. Chen, S.I., DO. ; Pierri, N. ; Presbitero, AF., Tracking the Economic Impact of COVID-19 and Mitigation Policies in Europe and the United States. IMF Working Papers, 2020(Working Paper No. 20/125).

7. Huang, C., et al., 6-month consequences of COVID-19 in patients discharged from hospital: a cohort study. The Lancet, 2021. 397(10270): p. 220-232.

8. ISARIC. Clinical Data Collection - The COVID-19 Case Report Forms (CRFs). 2020 [cited 202118 Feb]; Available from: https://isaric.org/research/covid-19-clinical-researchresources/covid-19-crf/.

9. Health, N.I.f. and E. Care. Overview / COVID-19 rapid guideline: managing the long-term effects of COVID-19 / Guidance / NICE. NG188 2021 [cited 202118 Feb]; Available from: https://www.nice.org.uk/guidance/ng188.

10. Organisation, W.H., Clinical management of COVID-19. 2020.

11. Council, M.R. MRC Dyspnoea scale / MRC Breathlessness scale. [cited 2021 March 26]; Available from: https://mrc.ukri.org/research/facilities-and-resources-for-researchers/mrcscales/mrc-dyspnoea-scale-mrc-breathlessness-scale/.

12. Organisation, W.H. Clinical management of COVID-19. 202013 november 2020]; Available from: https://www.who.int/publications/i/item/clinical-management-of-covid-19. 
medRxiv preprint doi: https://doi.org/10.1101/2021.05.05.21256710; this version posted May 11, 2021. The copyright holder for this preprint (which was not certified by peer review) is the author/funder, who has granted medRxiv a license to display the preprint in perpetuity. All rights reserved. No reuse allowed without permission.

Evolution of COVID-19 symptoms during the first 9 months after illness onset

Manuscript

13. Stronks, K., I. Kulu-Glasgow, and C. Agyemang, The utility of 'country of birth' for the classification of ethnic groups in health research: the Dutch experience. Ethnicity \& Health, 2009. 14(3): p. 255-269.

14. Organisation, W.H., WHO COVID-19 Case definition. Public health surveillance for COVID19, 2020(WHO/2019-nCoV/Surveillance_Case_Definition/2020.2).

15. Sigfrid, L., et al., Long Covid in adults discharged from UK hospitals after Covid-19: A prospective, multicentre cohort study using the ISARIC WHO Clinical Characterisation Protocol. medRxiv, 2021: p. 2021.03.18.21253888.

16. Logue, J.K., et al., Sequelae in Adults at 6 Months After COVID-19 Infection. JAMA Network Open, 2021. 4(2): p. e210830-e210830.

17. Ayoubkhani, D.G., C.; Jenkins, J. Update on long COVID prevalence estimate. ONS 2021; 1 April 2021:[Available from:

https://www.ons.gov.uk/peoplepopulationandcommunity/healthandsocialcare/conditionsandd iseases/bulletins/prevalenceofongoingsymptomsfollowingcoronaviruscovid19infectionintheuk /1april2021.

18. Havervall, S., et al., Symptoms and Functional Impairment Assessed 8 Months After Mild COVID-19 Among Health Care Workers. JAMA, 2021.

19. Nature Long COVID: let patients help define long-lasting COVID symptoms. 2020. 586, DOI: https://doi.org/10.1038/d41586-020-02796-2.

20. RIVM. Long COVID. 2021 [cited 20216 April]; Available from: https://www.rivm.nl/en/novelcoronavirus-covid-19/long-covid.

21. McLaren, L., Socioeconomic Status and Obesity. Epidemiologic Reviews, 2007. 29(1): p. 2948.

22. Kompaniyets, L.G., A.; Belay, B.; Freedman, D.; Sucosky, M.; Lange, S.; Gundlapalli, A.; Boehmer, T.; Blanck, H., Body Mass Index and Risk for COVID-19-Related Hospitalization, Intensive Care Unit Admission, Invasive Mechanical Ventilation, and Death - United States, March-December 2020., in MMWR Morb Mortal Wkly Rep. 2021. p. 355-361. 
medRxiv preprint doi: https://doi.org/10.1101/2021.05.05.21256710; this version posted May 11, 2021. The copyright holder for this preprint (which was not certified by peer review) is the author/funder, who has granted medRxiv a license to display the preprint in perpetuity.

All rights reserved. No reuse allowed without permission.

Evolution of COVID-19 symptoms during the first 9 months after illness onset

Manuscript

23. Sabes-Figuera, R., et al., The hidden cost of chronic fatigue to patients and their families. BMC Health Services Research, 2010. 10(1): p. 56.

24. Sykes, D.L., et al., Post-COVID-19 Symptom Burden: What is Long-COVID and How Should We Manage It? Lung, 2021. 199(2): p. 113-119.

25. Coyer, L., et al., Hospitalisation rates differed by city district and ethnicity during the first wave of COVID-19 in Amsterdam, the Netherlands. medRxiv, 2021: p.

2021.03.15.21253597.

26. Coyer, L., et al., SARS-CoV-2 antibody prevalence and determinants of six ethnic groups living in Amsterdam, the Netherlands: a population-based cross-sectional study, JuneOctober 2020. medRxiv, 2021: p. 2021.03.08.21252788.

27. Jewell, B.L., Monitoring differences between the SARS-CoV-2 B.1.1.7 variant and other lineages. The Lancet Public Health. 
medRxiv preprint doi: https://doi.org/10.1101/2021.05.05.21256710; this version posted May 11, 2021. The copyright holder for this preprint (which was not certified by peer review) is the author/funder, who has granted medRxiv a license to display the preprint in perpetuity.

All rights reserved. No reuse allowed without permission.

Evolution of COVID-19 symptoms during the first 9 months after illness onset

Manuscript

\section{Tables and Figures}

Table 1. Socio-demographic and clinical characteristics of participants of the RECoVERED study, May 2020-February 2021 in Amsterdam, the Netherlands, by clinical severity group

Table 2. Incidence proportion of the 18 symptoms at illness onset and within one and four weeks (the acute phase of disease) among prospectively-recruited participants, by clinical severity group

Figures 1a-e. Transition between levels of self-reported presence and severity of fatigue, cough, loss of smell and/or taste, myalgia and dyspnoea over time among prospectively-included participants

Figure 2. Kaplan-Meier plot of time from illness onset to complete recovery from symptoms, by clinical severity group

Figure 3. Univariable and multivariable Cox proportional hazard ratios of time to complete recovery for age, sex, BMI and comorbidity status at illness onset 
medRxiv preprint doi: https://doi.org/10.1101/2021.05.05.21256710; this version posted May 11,2021 . The copyright holder for this preprint (which was not certified by peer review) is the author/funder, who has granted medRxiv a license to display the preprint in perpetuity.

All rights reserved. No reuse allowed without permission.

Evolution of COVID-19 symptoms during the first 9 months after illness onset

Manuscript

Table 1. Socio-demographic and clinical characteristics of participants of the RECoVERED study, May 2020-February 2021 in Amsterdam, the Netherlands, by clinical severity group

\begin{tabular}{|c|c|c|c|c|c|c|}
\hline & Total & Mild & Moderate & Severe & Critical & p-value \\
\hline & $\mathrm{N}=301$ & $\mathrm{~N}=99$ & $\mathrm{~N}=140$ & $\mathrm{~N}=30$ & $\mathrm{~N}=32$ & \\
\hline \multicolumn{7}{|c|}{ Baseline socio-demographic and medical characteristics } \\
\hline Sex & & & & & & $<0.001$ \\
\hline Male & $167(55 \%)$ & $47(47 \%)$ & $81(58 \%)$ & $12(40 \%)$ & $27(84 \%)$ & \\
\hline Female & $134(45 \%)$ & $52(53 \%)$ & $59(42 \%)$ & $18(60 \%)$ & $5(16 \%)$ & \\
\hline Age, years & $\begin{array}{l}50.0(33.0- \\
62.0)\end{array}$ & $\begin{array}{l}39.0(27.0- \\
54.0)\end{array}$ & $\begin{array}{l}49.0(34.0- \\
62.5)\end{array}$ & $\begin{array}{l}62.0(50.0- \\
69.0)\end{array}$ & $\begin{array}{l}58.5(53.0- \\
62.0)\end{array}$ & $<0.001$ \\
\hline BMI, $\mathrm{kg} / \mathrm{m}^{2}$ & $\begin{array}{l}25.6(23.1- \\
29.4)\end{array}$ & $\begin{array}{l}24.4(22.8- \\
27.7)\end{array}$ & $\begin{array}{l}25.6(23.0- \\
29.4)\end{array}$ & $\begin{array}{l}28.1(26.1- \\
38.3)\end{array}$ & $\begin{array}{l}26.9(23.8- \\
29.5)\end{array}$ & 0.006 \\
\hline BMI category & & & & & & 0.005 \\
\hline Normal weight + & $121(40 \%)$ & $54(55 \%)$ & $53(38 \%)$ & $5(17 \%)$ & $9(28 \%)$ & \\
\hline Overweight & $90(30 \%)$ & $23(23 \%)$ & $42(30 \%)$ & $9(30 \%)$ & $16(50 \%)$ & \\
\hline Obese & $58(19 \%)$ & $14(14 \%)$ & $28(20 \%)$ & $9(30 \%)$ & $7(22 \%)$ & \\
\hline Missing & $32(11 \%)$ & $8(8 \%)$ & $17(12 \%)$ & $7(23 \%)$ & $0(0 \%)$ & \\
\hline Ethnic origin & & & & & & 0.023 \\
\hline Netherlands & $163(54 \%)$ & $62(63 \%)$ & $73(52 \%)$ & $10(33 \%)$ & $18(56 \%)$ & \\
\hline Morocco & $10(3 \%)$ & $4(4 \%)$ & $3(2 \%)$ & $1(3 \%)$ & $2(6 \%)$ & \\
\hline Asia, Middle East, Africa & $27(9 \%)$ & $5(5 \%)$ & $14(10 \%)$ & $5(17 \%)$ & $3(9 \%)$ & \\
\hline \multicolumn{7}{|l|}{$\begin{array}{l}\text { South America, Caribbean } \\
\text { (including Suriname and }\end{array}$} \\
\hline $\begin{array}{r}\text { Other (Europe, Russia, } \\
\text { Australia, Canada, USA, } \\
\text { New Zealand }\end{array}$ & $24(8 \%)$ & $11(11 \%)$ & $11(8 \%)$ & $1(3 \%)$ & $1(3 \%)$ & \\
\hline Missing & $41(14 \%)$ & $13(13 \%)$ & $20(14 \%)$ & $5(17 \%)$ & $3(9 \%)$ & \\
\hline Smoking & & & & & & 0.57 \\
\hline Non-smoker & $162(54 \%)$ & $56(57 \%)$ & $71(51 \%)$ & $15(50 \%)$ & $20(63 \%)$ & \\
\hline Smoker & $18(6 \%)$ & $8(8 \%)$ & $9(6 \%)$ & $1(3 \%)$ & $0(0 \%)$ & \\
\hline Ex-smoker & $78(26 \%)$ & $22(22 \%)$ & $41(29 \%)$ & $7(23 \%)$ & $8(25 \%)$ & \\
\hline Missing & $43(14 \%)$ & $13(13 \%)$ & $19(14 \%)$ & $7(23 \%)$ & $4(13 \%)$ & \\
\hline Highest level of education & & & & & & $<0.001$ \\
\hline $\begin{array}{r}\text { None, primary or } \\
\text { secondary education }\end{array}$ & $36(12 \%)$ & $7(7 \%)$ & $21(15 \%)$ & $5(17 \%)$ & $3(9 \%)$ & \\
\hline Vocational training & $57(19 \%)$ & $8(8 \%)$ & $29(21 \%)$ & $7(23 \%)$ & $13(41 \%)$ & \\
\hline University education & $164(54 \%)$ & $71(72 \%)$ & $70(50 \%)$ & $11(37 \%)$ & $12(38 \%)$ & \\
\hline Missing & $44(15 \%)$ & $13(13 \%)$ & $20(14 \%)$ & $7(23 \%)$ & $4(13 \%)$ & \\
\hline Number of comorbidities* & & & & & & $<0.001$ \\
\hline 0 & $179(59 \%)$ & $76(77 \%)$ & $85(61 \%)$ & $7(23 \%)$ & $11(34 \%)$ & \\
\hline 1 & $60(20 \%)$ & $14(14 \%)$ & $28(20 \%)$ & $8(27 \%)$ & $10(31 \%)$ & \\
\hline 2 & $36(12 \%)$ & $6(6 \%)$ & $18(13 \%)$ & $7(23 \%)$ & $5(16 \%)$ & \\
\hline 3 or more & $26(9 \%)$ & $3(3 \%)$ & $9(6 \%)$ & $8(27 \%)$ & $6(19 \%)$ & \\
\hline Cardiovascular disease & $77(26 \%)$ & $13(14 \%)$ & $36(26 \%)$ & $17(59 \%)$ & $11(34 \%)$ & $<0.001$ \\
\hline Diabetes & $39(13 \%)$ & $5(5 \%)$ & $15(11 \%)$ & $10(34 \%)$ & $9(28 \%)$ & $<0.001$ \\
\hline $\begin{array}{l}\text { Chronic respiratory } \\
\text { disease }\end{array}$ & $22(8 \%)$ & $1(1 \%)$ & $11(8 \%)$ & $7(24 \%)$ & $3(9 \%)$ & $<0.001$ \\
\hline Cancer & $15(5 \%)$ & $6(6 \%)$ & $6(4 \%)$ & $1(3 \%)$ & $2(6 \%)$ & 0.84 \\
\hline Immunosuppressed & $18(6 \%)$ & $1(1 \%)$ & $7(5 \%)$ & $5(17 \%)$ & $5(16 \%)$ & 0.001 \\
\hline Other comorbidities & $81(28 \%)$ & $19(20 \%)$ & $43(31 \%)$ & $9(31 \%)$ & $10(32 \%)$ & 0.28 \\
\hline
\end{tabular}


medRxiv preprint doi: https://doi.org/10.1101/2021.05.05.21256710; this version posted May 11, 2021. The copyright holder for this preprint (which was not certified by peer review) is the author/funder, who has granted medRxiv a license to display the preprint in perpetuity.

All rights reserved. No reuse allowed without permission.

Evolution of COVID-19 symptoms during the first 9 months after illness onset

Manuscript

\begin{tabular}{|c|c|c|c|c|c|c|}
\hline & Total & Mild & Moderate & Severe & Critical & p-value \\
\hline & $\mathrm{N}=301$ & $\mathrm{~N}=99$ & $\mathrm{~N}=140$ & $\mathrm{~N}=30$ & $\mathrm{~N}=32$ & \\
\hline \multicolumn{7}{|c|}{ COVID-19 clinical characteristics } \\
\hline $\begin{array}{l}\text { Physical measurements at } \\
\text { enrolment and day } 7 \text { study } \\
\text { visit }\end{array}$ & & & & & & \\
\hline $\begin{array}{l}\text { Maximum heart rate, } \\
\text { beats/min }\end{array}$ & $81(72-93)$ & $74(66-81)$ & $83(73-93)$ & $93(84-105)$ & - & $<0.001$ \\
\hline $\begin{array}{l}\text { Maximum respiratory rate, } \\
\text { breaths } / \text { min }\end{array}$ & $20(16-24)$ & $16(16-16)$ & $20(20-24)$ & $26(23-32)$ & - & $<0.001$ \\
\hline $\begin{array}{l}\text { Minimum oxygen saturation } \\
\text { on room air }\end{array}$ & $97(93-98)$ & 98 (97-99) & $96(94-98)$ & $88(86-89)$ & - & $<0.001$ \\
\hline COVID-19 symptom status & & & & & & 0.14 \\
\hline Symptomatic & 297 (99\%) & $96(97 \%)$ & $140(100 \%)$ & $29(97 \%)$ & $32(100 \%)$ & \\
\hline Asymptomatic & $4(1 \%)$ & $3(3 \%)$ & $0(0 \%)$ & $1(3 \%)$ & $0(0 \%)$ & \\
\hline COVID-19 hospitalisation & $131(44 \%)$ & $6(6 \%)$ & $66(47 \%)$ & $27(90 \%)$ & $32(100 \%)$ & $<0.001$ \\
\hline COVID-19 ICU admission & $32(11 \%)$ & $0(0 \%)$ & $0(0 \%)$ & $0(0 \%)$ & $32(100 \%)$ & $<0.001$ \\
\hline $\begin{array}{l}\text { Days from illness onset to } \\
\text { COVID-19 diagnosis }\end{array}$ & $5(2-10)$ & $3(1-8)$ & $5(3-11)$ & $9(7-14)$ & $8(6-11)$ & $<0.001$ \\
\hline \multicolumn{7}{|l|}{ Days from illness onset to: } \\
\hline Hospitalisation & $9(6-15)$ & $12(4-43)$ & $10(6-15)$ & $14(9-16)$ & $7(5-9)$ & 0.007 \\
\hline ICU admission & $10(7-11)$ & - & - & - & $10(7-11)$ & \\
\hline $\begin{array}{l}\text { Died during follow-up (n } \\
\text { only) }\end{array}$ & 1 & 0 & 1 & 0 & 0 & - \\
\hline \multicolumn{7}{|l|}{ Treatment received } \\
\hline Dexamethasone & $29(13 \%)$ & $0(0 \%)$ & $19(19 \%)$ & $8(38 \%)$ & $2(10 \%)$ & $<0.001$ \\
\hline Remdesivir & $15(7 \%)$ & $0(0 \%)$ & $7(7 \%)$ & $6(26 \%)$ & $2(9 \%)$ & $<0.001$ \\
\hline Oxygen therapy & $111(38 \%)$ & $0(0 \%)$ & $55(40 \%)$ & $26(84 \%)$ & $30(97 \%)$ & $<0.001$ \\
\hline $\begin{array}{l}\text { Serology and PCR results } \\
\text { at enrolment } \\
\text { (prospectively-enrolled } \\
\text { participants only) }\end{array}$ & $\mathrm{N}=210$ & $\mathrm{~N}=86$ & $\mathrm{~N}=108$ & $\mathrm{~N}=15$ & $N=1$ & \\
\hline $\begin{array}{r}\text { Positive nasopharyngeal } \\
\text { PCR test }\end{array}$ & $119(57 \%)$ & $46(53 \%)$ & $63(58 \%)$ & $9(60 \%)$ & $1(100 \%)$ & 0.56 \\
\hline Positive throat PCR test & $94(45 \%)$ & $44(51 \%)$ & $46(43 \%)$ & $3(20 \%)$ & $1(100 \%)$ & 0.010 \\
\hline $\begin{array}{r}\text { Positive SARS-CoV-2 } \\
\text { serology } y^{\ddagger}\end{array}$ & $185(88 \%)$ & 75 (87\%) & 95 (88\%) & $14(93 \%)$ & $1(100 \%)$ & 0.67 \\
\hline \multicolumn{7}{|c|}{ Study characteristics } \\
\hline Recruitment site & & & & & & - \\
\hline PHSA & $161(53 \%)$ & $85(86 \%)$ & $72(51 \%)$ & $4(13 \%)$ & $0(0 \%)$ & \\
\hline Hospital & $140(47 \%)$ & $14(14 \%)$ & $68(49 \%)$ & $26(87 \%)$ & $32(100 \%)$ & \\
\hline Type of inclusion & & & & & & $<0.001$ \\
\hline Prospective & $210(70 \%)$ & $86(87 \%)$ & $108(77 \%)$ & $15(50 \%)$ & $1(3 \%)$ & \\
\hline Retrospective & $91(30 \%)$ & $13(13 \%)$ & $32(23 \%)$ & $15(50 \%)$ & $31(97 \%)$ & \\
\hline $\begin{array}{l}\text { Time from illness onset to } \\
\text { enrolment, days }\end{array}$ & $11(6-66)$ & $7(4-11)$ & $11(6-38)$ & $42(17-82)$ & $87(72-96)$ & $<0.001$ \\
\hline Prospective participants only & $8(5-12)$ & $6(4-9)$ & $8(6-15)$ & $16(11-18)$ & $11(11-11)$ & $<0.001$ \\
\hline $\begin{array}{r}\text { Retrospective participants } \\
\text { only }\end{array}$ & $85(73-94)$ & $92(66-94)$ & 85 (76-92) & $82(45-99)$ & $88(73-96)$ & 0.98 \\
\hline $\begin{array}{l}\text { Follow-up time from } \\
\text { enrolment, days }\end{array}$ & $\begin{array}{l}174.0(97.0- \\
256.0)\end{array}$ & $\begin{array}{l}139.0(81.0- \\
250.0)\end{array}$ & $\begin{array}{l}153.0(86.5- \\
251.0)\end{array}$ & $\begin{array}{l}200.0 \\
(111.0- \\
261.0)\end{array}$ & $\begin{array}{l}248.5(240.0- \\
256.5)\end{array}$ & 0.002 \\
\hline Prospective participants only & $\begin{array}{l}125.0(81.0- \\
209.0)\end{array}$ & $\begin{array}{l}114.0(75.0- \\
200.0)\end{array}$ & $\begin{array}{l}129.0(81.5- \\
215.5)\end{array}$ & $\begin{array}{l}158.0(83.0- \\
167.0)\end{array}$ & $\begin{array}{l}110.0(110.0- \\
110.0)\end{array}$ & 0.83 \\
\hline $\begin{array}{r}\text { Retrospective participants } \\
\text { only }\end{array}$ & $\begin{array}{l}256.0 \\
(243.0- \\
263.0)\end{array}$ & $\begin{array}{l}271.0 \\
(248.0- \\
286.0)\end{array}$ & $\begin{array}{l}257.0 \\
(243.5- \\
264.0)\end{array}$ & $\begin{array}{l}261.0 \\
(256.0- \\
263.0)\end{array}$ & $\begin{array}{l}249.0(240.0- \\
257.0)\end{array}$ & 0.066 \\
\hline Lost to follow-up (n only) & 42 & 12 & 23 & 2 & 5 & - \\
\hline
\end{tabular}

Continuous variables presented as median (IQR) and compared using the Kruskal-Wallis test; categorical and binary variables presented as $n(\%)$ and compared using the Pearson $x^{2}$ test (or Fisher exact test if $\left.n<5\right)$. Clinical severity groups defined as: mild as having a $\mathrm{RR}<20 / \mathrm{min}$ and $\mathrm{SpO} 2$ on room air $>94 \%$ at both day 0 and 7 ; moderate disease as having a 
medRxiv preprint doi: https://doi.org/10.1101/2021.05.05.21256710; this version posted May 11, 2021. The copyright holder for this preprint (which was not certified by peer review) is the author/funder, who has granted medRxiv a license to display the preprint in perpetuity.

All rights reserved. No reuse allowed without permission.

Evolution of COVID-19 symptoms during the first 9 months after illness onset

Manuscript

RR 20-30/min, SpO2 90-94\% and/or receiving oxygen therapy at day 0 or 7 ; severe disease as having a $R R>30 / m i n$ or $\mathrm{SpO} 2<90 \%$ at day 0 or 7 ; critical disease as requiring ICU admission. BMI=Body mass index; PCR=Polymerase Chain Reaction; PHSA=Public Health Service of Amsterdam.

†Normal BMl group includes 3 individuals with $\mathrm{BMl}<18.5$ but $>17.0 \mathrm{~kg} / \mathrm{m}^{2}$. Physical measurements not displayed for individuals with critical disease due to unreliability of measurements at admission for critically-ill patients.

${ }^{*}$ COVID-related comorbidities include: cardiovascular disease (including hypertension), chronic pulmonary disease (excluding asthma), renal disease, liver disease, cancer, immunosuppression (excluding HIV, including previous organ transplantation).

‡ SARS-CoV-2-specific antibodies were measured using the WANTAI SARS-CoV-2 Ab ELISA and a positive test result was defined according to the manufacturer's instructions. 
Table 2. Incidence proportion of 18 symptoms at illness onset and within one and four weeks after illness onset (the acute phase of disease) among prospectively-recruited participants, by clinical severity group

\begin{tabular}{|c|c|c|c|c|c|c|c|c|c|c|c|c|c|}
\hline & \multicolumn{5}{|c|}{ On day of illness onset } & \multicolumn{4}{|c|}{ Within one week from illness onset } & \multicolumn{4}{|c|}{ Within four weeks from illness onset } \\
\hline & $\begin{array}{c}\text { All } \\
\text { patients }\end{array}$ & $\begin{array}{c}\text { Mild } \\
\text { disease }\end{array}$ & $\begin{array}{l}\text { Moderate } \\
\text { disease }\end{array}$ & $\begin{array}{l}\text { Severe/ } \\
\text { Critical } \\
\text { disease }\end{array}$ & p-value & $\begin{array}{c}\text { Mild } \\
\text { disease }\end{array}$ & $\begin{array}{l}\text { Moderate } \\
\text { disease }\end{array}$ & $\begin{array}{l}\text { Severe/ } \\
\text { Critical } \\
\text { disease }\end{array}$ & p-value & $\begin{array}{c}\text { Mild } \\
\text { disease }\end{array}$ & $\begin{array}{c}\text { Moderate } \\
\text { disease }\end{array}$ & $\begin{array}{l}\text { Severe/ } \\
\text { Critical } \\
\text { disease }\end{array}$ & p-value \\
\hline & $\mathrm{N}=210$ & $\mathrm{~N}=86$ & $\mathrm{~N}=108$ & $\mathrm{~N}=16$ & & $\mathrm{~N}=86$ & $\mathrm{~N}=108$ & $\mathrm{~N}=16$ & & $\mathrm{~N}=83$ & $\mathrm{~N}=105$ & $\mathrm{~N}=15$ & \\
\hline Fatigue & $107(51 \%)$ & $46(53 \%)$ & $55(51 \%)$ & $6(38 \%)$ & 0.50 & $70(81 \%)$ & $76(70 \%)$ & $10(63 \%)$ & 0.12 & $72(87 \%)$ & $87(83 \%)$ & $11(73 \%)$ & 0.37 \\
\hline Cough & $75(36 \%)$ & $30(35 \%)$ & $40(37 \%)$ & $5(31 \%)$ & 0.88 & $51(59 \%)$ & $65(60 \%)$ & $9(56 \%)$ & 0.95 & $55(66 \%)$ & $75(71 \%)$ & $10(67 \%)$ & 0.68 \\
\hline $\begin{array}{l}\text { Loss of smell } \\
\text { and/or taste }\end{array}$ & $41(20 \%)$ & $19(22 \%)$ & $20(19 \%)$ & $2(13 \%)$ & 0.66 & $60(70 \%)$ & $51(47 \%)$ & 7 (44\%) & 0.004 & $66(80 \%)$ & $62(59 \%)$ & $7(47 \%)$ & 0.004 \\
\hline Headache & $76(36 \%)$ & $39(45 \%)$ & $33(31 \%)$ & $4(25 \%)$ & 0.066 & 56 (65\%) & 52 (48\%) & $6(38 \%)$ & 0.022 & $60(72 \%)$ & $61(58 \%)$ & $6(40 \%)$ & 0.025 \\
\hline Rhinorrhoea & $55(26 \%)$ & $26(30 \%)$ & $28(26 \%)$ & $1(6 \%)$ & 0.13 & $55(64 \%)$ & $53(49 \%)$ & $3(19 \%)$ & 0.002 & $61(73 \%)$ & $60(57 \%)$ & $6(40 \%)$ & 0.014 \\
\hline Myalgia & $73(35 \%)$ & $34(40 \%)$ & 35 (32\%) & $4(25 \%)$ & 0.46 & $49(57 \%)$ & $56(52 \%)$ & $8(50 \%)$ & 0.77 & $56(67 \%)$ & $61(58 \%)$ & $9(60 \%)$ & 0.47 \\
\hline Fever & 77 (37\%) & 29 (34\%) & 40 (37\%) & $8(50 \%)$ & 0.46 & $41(48 \%)$ & $56(52 \%)$ & 11 (69\%) & 0.30 & 45 (54\%) & $64(61 \%)$ & $12(75 \%)$ & 0.21 \\
\hline $\begin{array}{l}\text { Loss of } \\
\text { appetite }\end{array}$ & $56(27 \%)$ & $22(26 \%)$ & 31 (29\%) & $3(19 \%)$ & 0.72 & $41(48 \%)$ & 57 (53\%) & $9(56 \%)$ & 0.74 & 45 (54\%) & $66(63 \%)$ & $10(67 \%)$ & 0.44 \\
\hline Dyspnoea & 37 (18\%) & $10(12 \%)$ & 26 (24\%) & $1(6 \%)$ & 0.042 & 32 (37\%) & $50(46 \%)$ & $5(31 \%)$ & 0.31 & $36(43 \%)$ & $68(65 \%)$ & $10(67 \%)$ & 0.010 \\
\hline Sore throat & $52(25 \%)$ & 27 (31\%) & $24(22 \%)$ & $1(6 \%)$ & 0.069 & $48(56 \%)$ & $43(40 \%)$ & $3(19 \%)$ & 0.007 & $50(60 \%)$ & $51(49 \%)$ & $5(33 \%)$ & 0.086 \\
\hline Diarrhoea & $23(11 \%)$ & $9(10 \%)$ & $12(11 \%)$ & $2(13 \%)$ & 0.94 & $24(28 \%)$ & $26(24 \%)$ & $4(25 \%)$ & 0.86 & $28(34 \%)$ & $40(38 \%)$ & $4(27 \%)$ & 0.61 \\
\hline Chest pain & $19(9 \%)$ & 8 (9\%) & $8(7 \%)$ & $3(19 \%)$ & 0.27 & $26(30 \%)$ & $24(22 \%)$ & $4(25 \%)$ & 0.44 & 28 (34\%) & 37 (35\%) & $6(40 \%)$ & 0.90 \\
\hline Nausea & $25(12 \%)$ & $10(12 \%)$ & $14(13 \%)$ & $1(6 \%)$ & 0.85 & $20(23 \%)$ & 32 (30\%) & 3 (19\%) & 0.53 & 23 (28\%) & 39 (37\%) & $3(20 \%)$ & 0.23 \\
\hline $\begin{array}{l}\text { Abdominal } \\
\text { pain }\end{array}$ & $17(8 \%)$ & $8(9 \%)$ & $9(8 \%)$ & $0(0 \%)$ & 0.64 & 20 (23\%) & $22(20 \%)$ & 3 (19\%) & 0.90 & $26(31 \%)$ & $30(29 \%)$ & $2(13 \%)$ & 0.37 \\
\hline Arthralgia & 26 (12\%) & $11(13 \%)$ & $14(13 \%)$ & $1(6 \%)$ & 0.90 & 21 (24\%) & $16(15 \%)$ & $2(13 \%)$ & 0.22 & $23(28 \%)$ & $28(27 \%)$ & $4(27 \%)$ & 1.00 \\
\hline Confusion & 15 (7\%) & $10(12 \%)$ & $5(5 \%)$ & $0(0 \%)$ & 0.11 & $14(16 \%)$ & $12(11 \%)$ & $2(13 \%)$ & 0.54 & $16(19 \%)$ & $21(20 \%)$ & $3(20 \%)$ & 1.00 \\
\hline Wheeze & $11(5 \%)$ & $2(2 \%)$ & $8(7 \%)$ & $1(6 \%)$ & 0.21 & $8(9 \%)$ & $15(14 \%)$ & $3(19 \%)$ & 0.44 & $810 \%)$ & 20 (19\%) & $3(20 \%)$ & 0.16 \\
\hline Skin rash & $5(2 \%)$ & $2(2 \%)$ & $3(3 \%)$ & $0(0 \%)$ & 1.00 & $5(6 \%)$ & $4(4 \%)$ & $0(0 \%)$ & 0.76 & $8(10 \%)$ & $10(10 \%)$ & $0(0 \%)$ & 0.60 \\
\hline
\end{tabular}

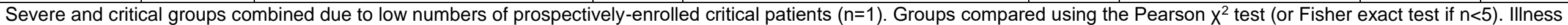

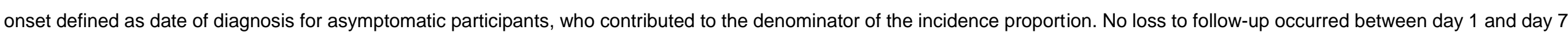
after illness onset. Loss to follow-up between day 7 and 28 after illness onset was minimal: $n=3$ in mild group, $n=3$ in moderate group, $n=1$ in severe group. 
medRxiv preprint doi: https://doi.org/10.1101/2021.05.05.21256710; this version posted May 11, 2021. The copyright holder for this preprint (which was not certified by peer review) is the author/funder, who has granted medRxiv a license to display the preprint in perpetuity.

All rights reserved. No reuse allowed without permission.

Evolution of COVID-19 symptoms during the first 9 months after illness onset

Manuscript

\section{Figure 1a-e. Transition between levels of self-reported presence and severity of fatigue, cough,} loss of smell and/or taste, myalgia and dyspnoea over time among prospectively-included participants

Median time from illness onset to recruitment was 8 days (IQR=5-12), therefore visit days in transition plots approximately correspond to day 8 , day 15 and day 36 since illness onset. Vertical bars represent the number of participants per severity level of the symptom at each day of follow-up. Severity level was defined as the maximum severity experienced by the study participant since the last study visit, i.e. the severity level reported at day 7 of follow-up represents the maximum severity experienced between recruitment and day 7 of followup. The size of the streams encodes the number of study participants who transitioned from one severity level to another; transitioning from any severity level to "none" represents recovery from that symptom.

Figure 1a. Fatigue

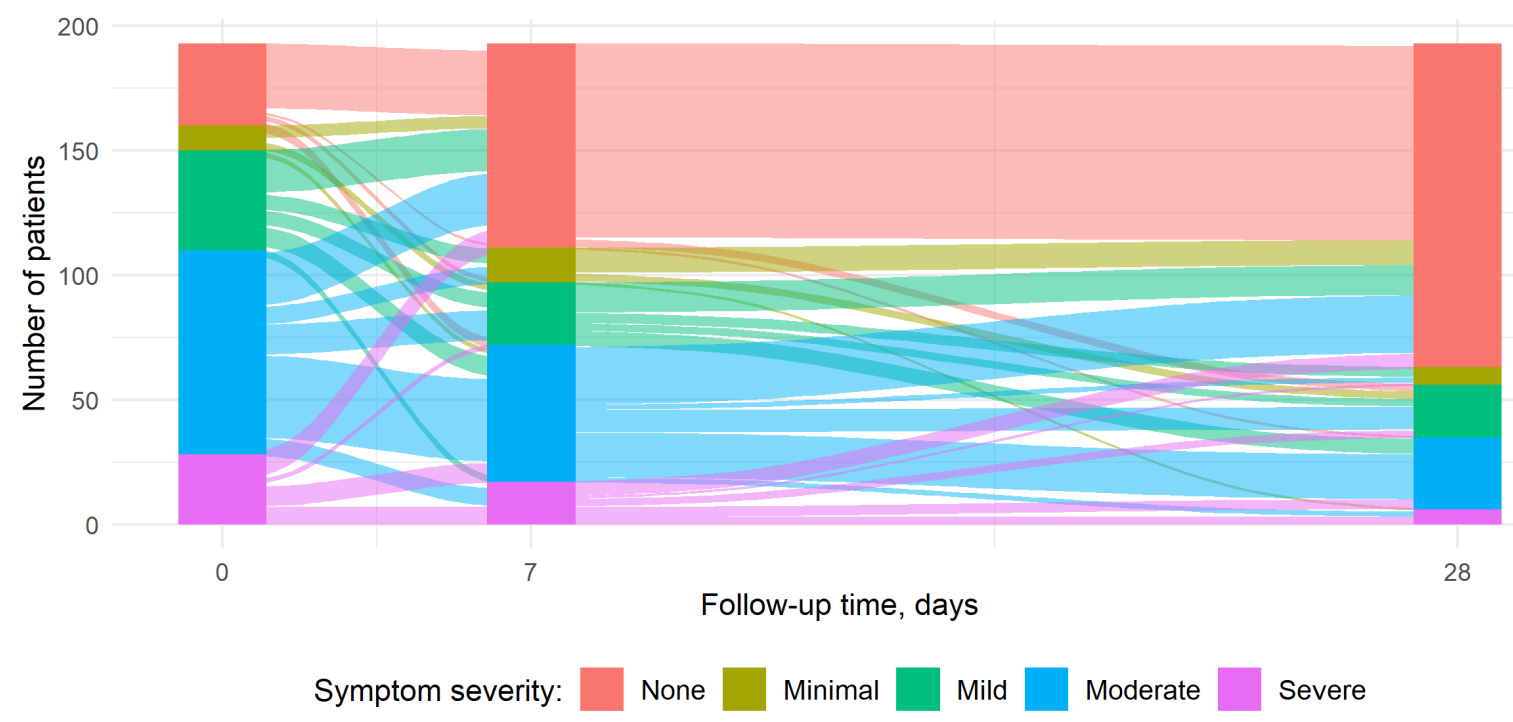

Figure 1b. Cough

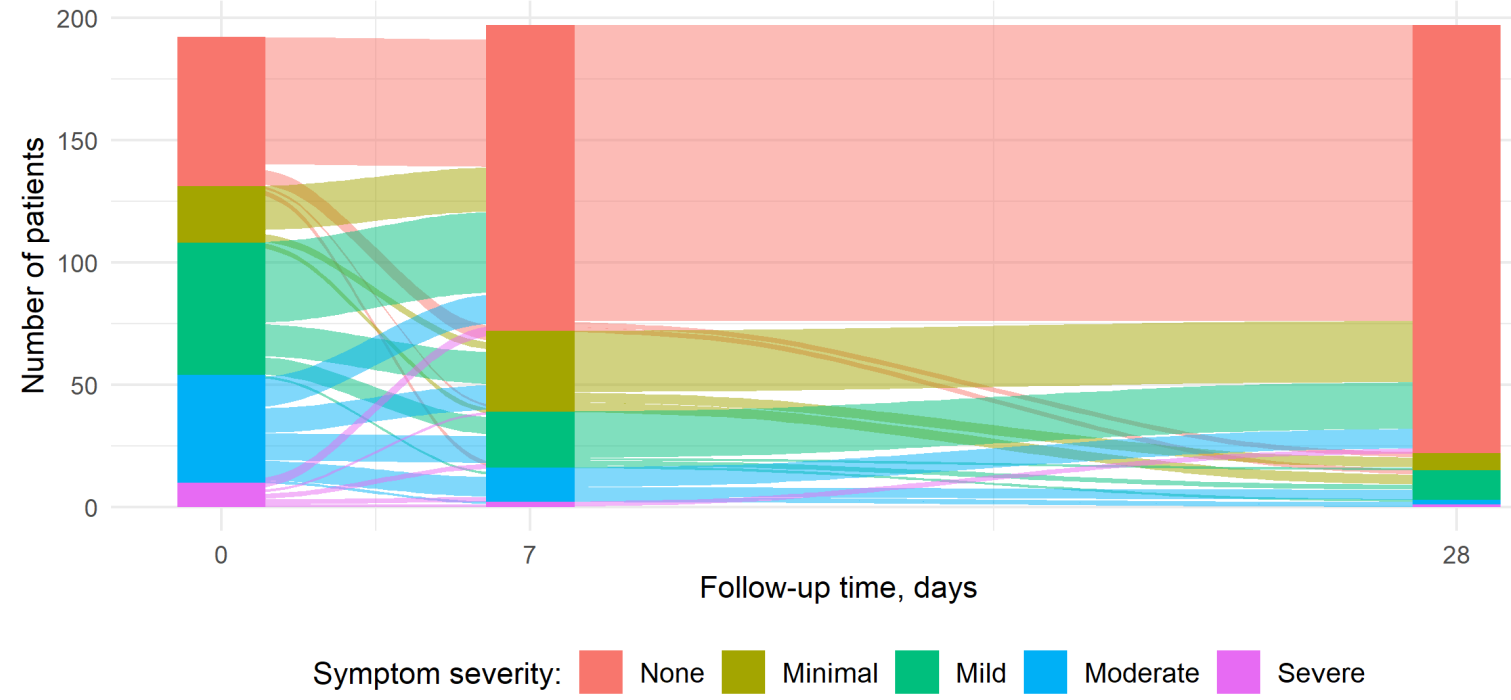


medRxiv preprint doi: https://doi.org/10.1101/2021.05.05.21256710; this version posted May 11, 2021. The copyright holder for this preprint (which was not certified by peer review) is the author/funder, who has granted medRxiv a license to display the preprint in perpetuity.

All rights reserved. No reuse allowed without permission.

Evolution of COVID-19 symptoms during the first 9 months after illness onset

Manuscript

\section{Figure 1c. Loss of smell and/or taste}

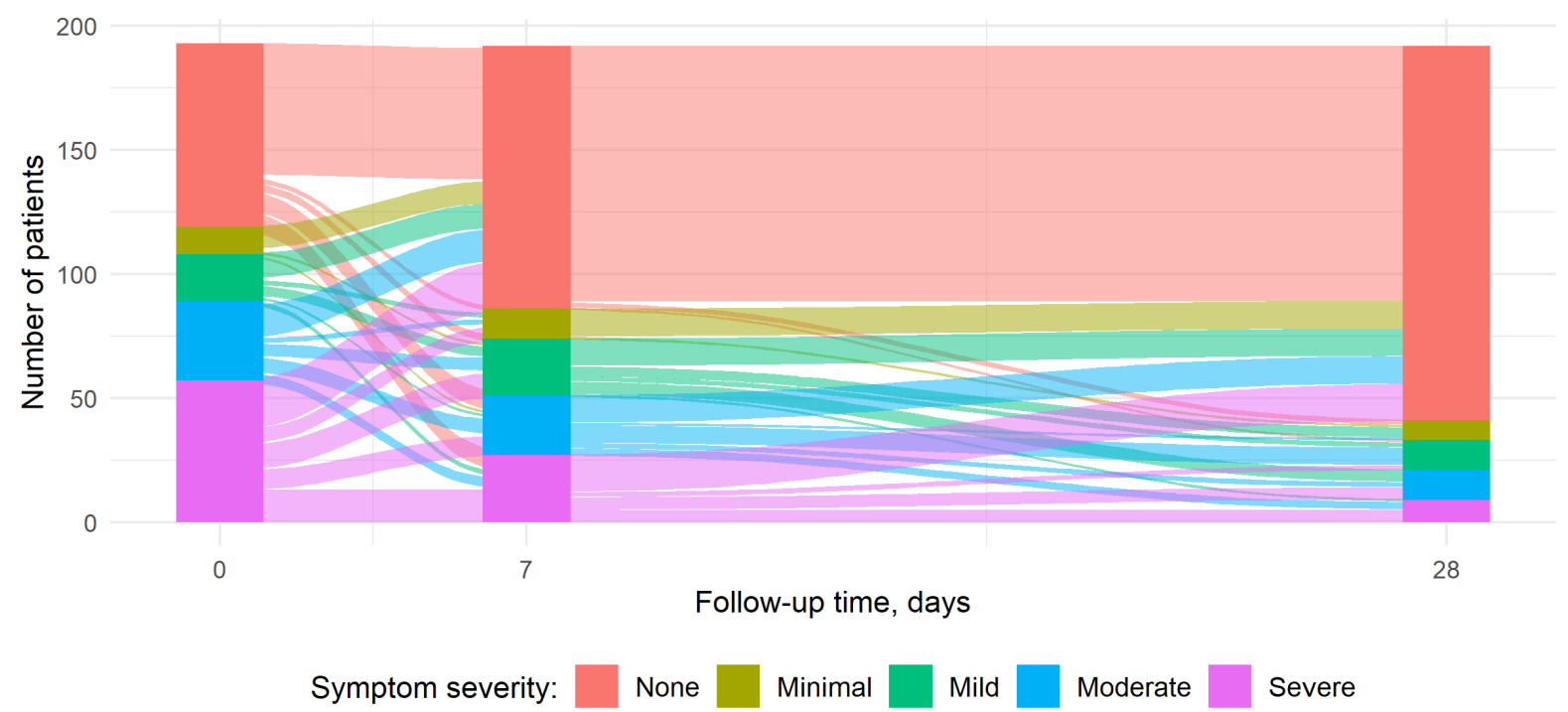

Figure 1d. Myalgia

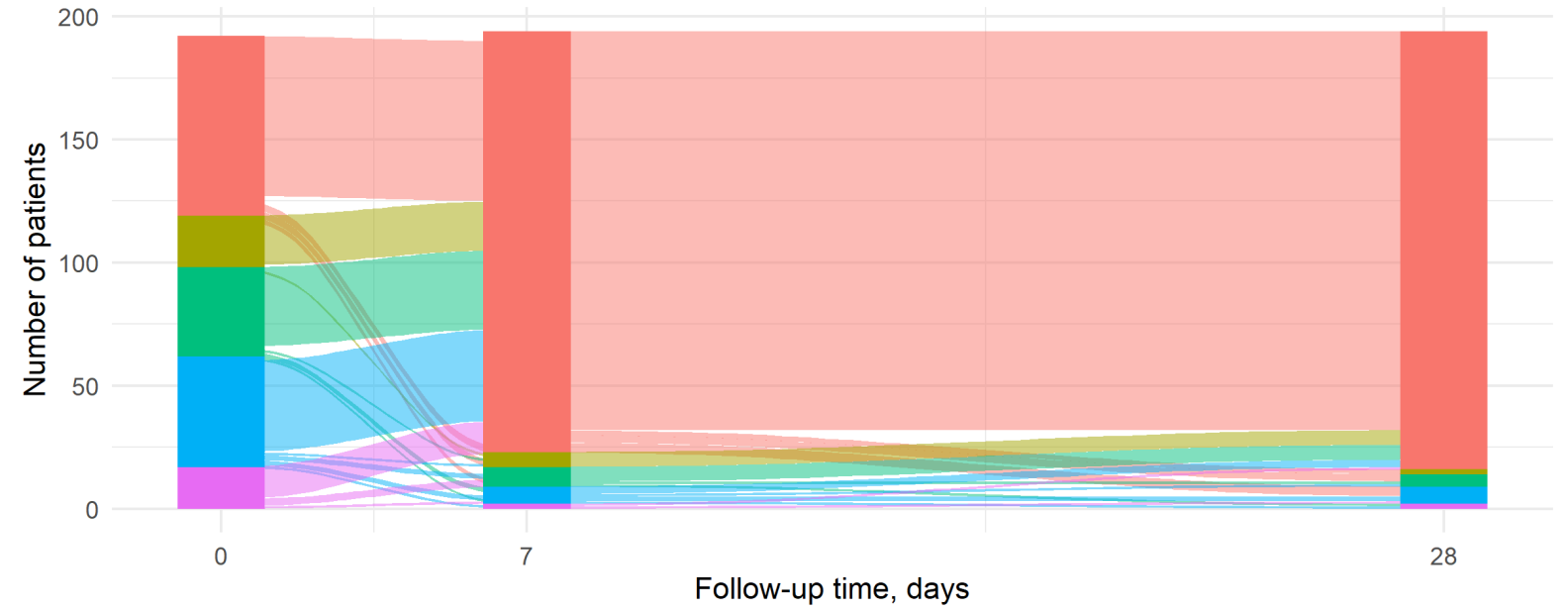

Symptom severity: None Minimal __ Mild __ Moderate Severe 
medRxiv preprint doi: https://doi.org/10.1101/2021.05.05.21256710; this version posted May 11, 2021. The copyright holder for this preprint (which was not certified by peer review) is the author/funder, who has granted medRxiv a license to display the preprint in perpetuity.

All rights reserved. No reuse allowed without permission.

Evolution of COVID-19 symptoms during the first 9 months after illness onset

Manuscript

\section{Figure 1e. Dyspnoea†}

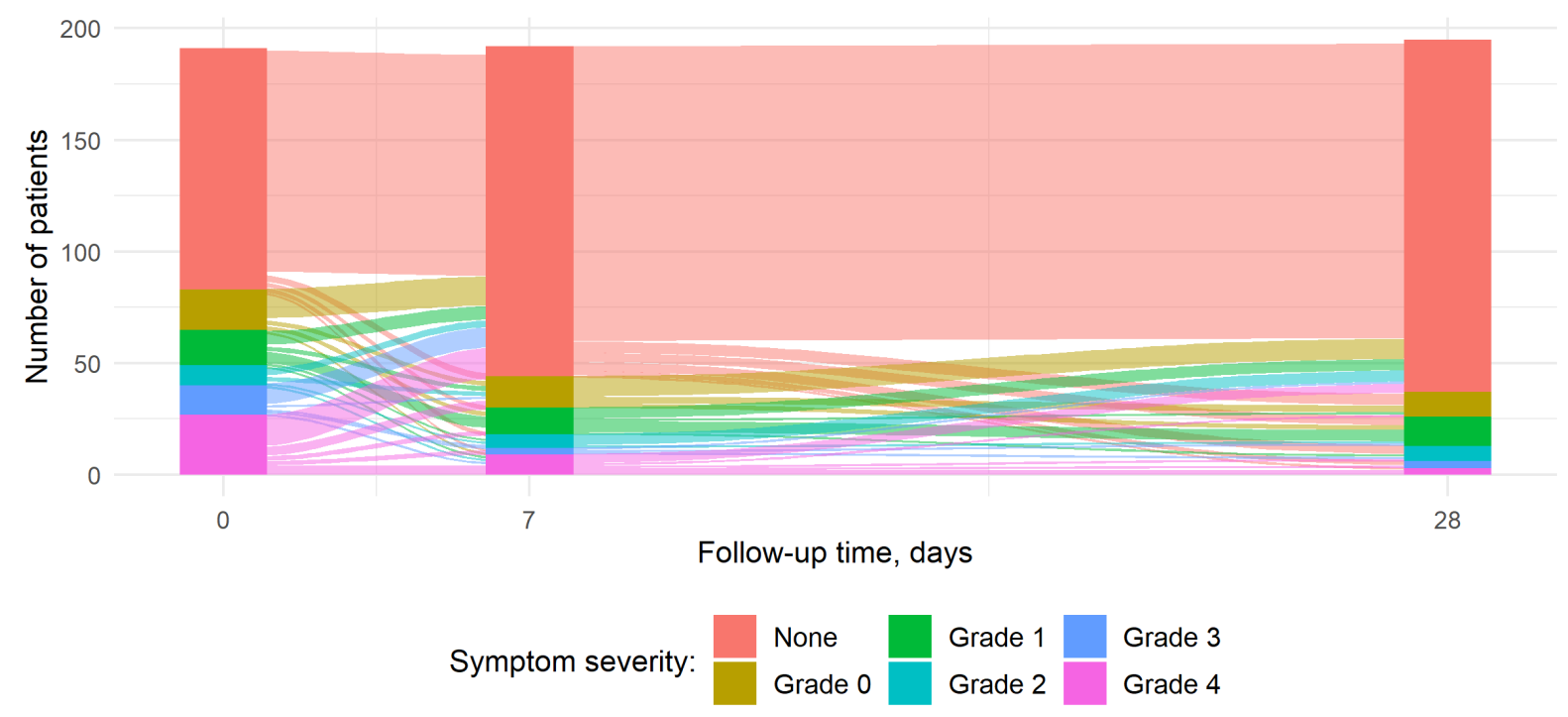

†mMRC Score: Grade 0 = breathlessness only on strenuous exercise; Grade 1 = shortness of breath when hurrying on the level or walking up a slight hill; Grade 2 = walks slower than people of same age on the level because of breathlessness or has to stop to catch breath when walking at their own pace on the level; Grade $3=$ stops for breath after walking $\sim 100 \mathrm{~m}$ or after few minutes on the level; and Grade 4 = too breathless to leave the house, or breathless when dressing or undressing. 
medRxiv preprint doi: https://doi.org/10.1101/2021.05.05.21256710; this version posted May 11, 2021. The copyright holder for this preprint (which was not certified by peer review) is the author/funder, who has granted medRxiv a license to display the preprint in perpetuity.

All rights reserved. No reuse allowed without permission.

Evolution of COVID-19 symptoms during the first 9 months after illness onset

Manuscript

Figure 2. Kaplan-Meier plot of time from illness onset to complete recovery from symptoms, by clinical severity group

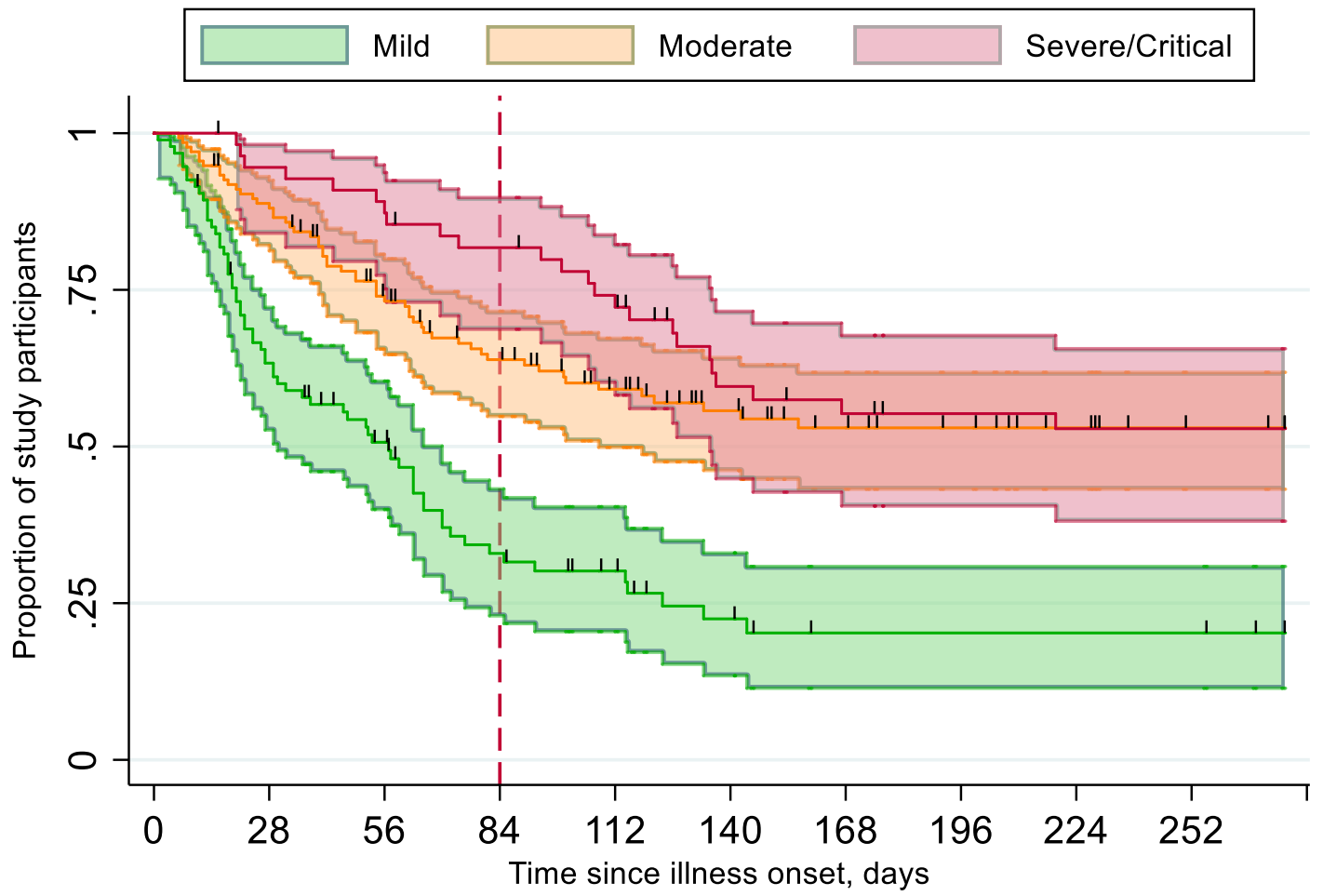

Number at risk

$\begin{array}{lcccccccccc}\text { Mild } & 94 & 58 & 41 & 24 & 18 & 11 & 7 & 7 & 7 & 7 \\ \text { Moderate } & 135 & 118 & 91 & 74 & 58 & 44 & 36 & 32 & 27 & 22 \\ \text { Severe/Critical } & 56 & 52 & 49 & 44 & 39 & 28 & 25 & 23 & 22 & 22\end{array}$

Clinical severity groups of severe and critically severe COVID-19 combined due to small numbers in the critical severity group. Dashed red line denotes cut-off point of 12 weeks (as per NICE definition of post-COVID syndrome); black vertical lines indicate time-points at which participants were censored. 
Figure 3. Univariable and multivariable Cox proportional hazard ratios of time to complete recovery for age, sex, BMI and comorbidity status at illness onset

\section{Univariable Model}

\section{Determinants at illness onset}

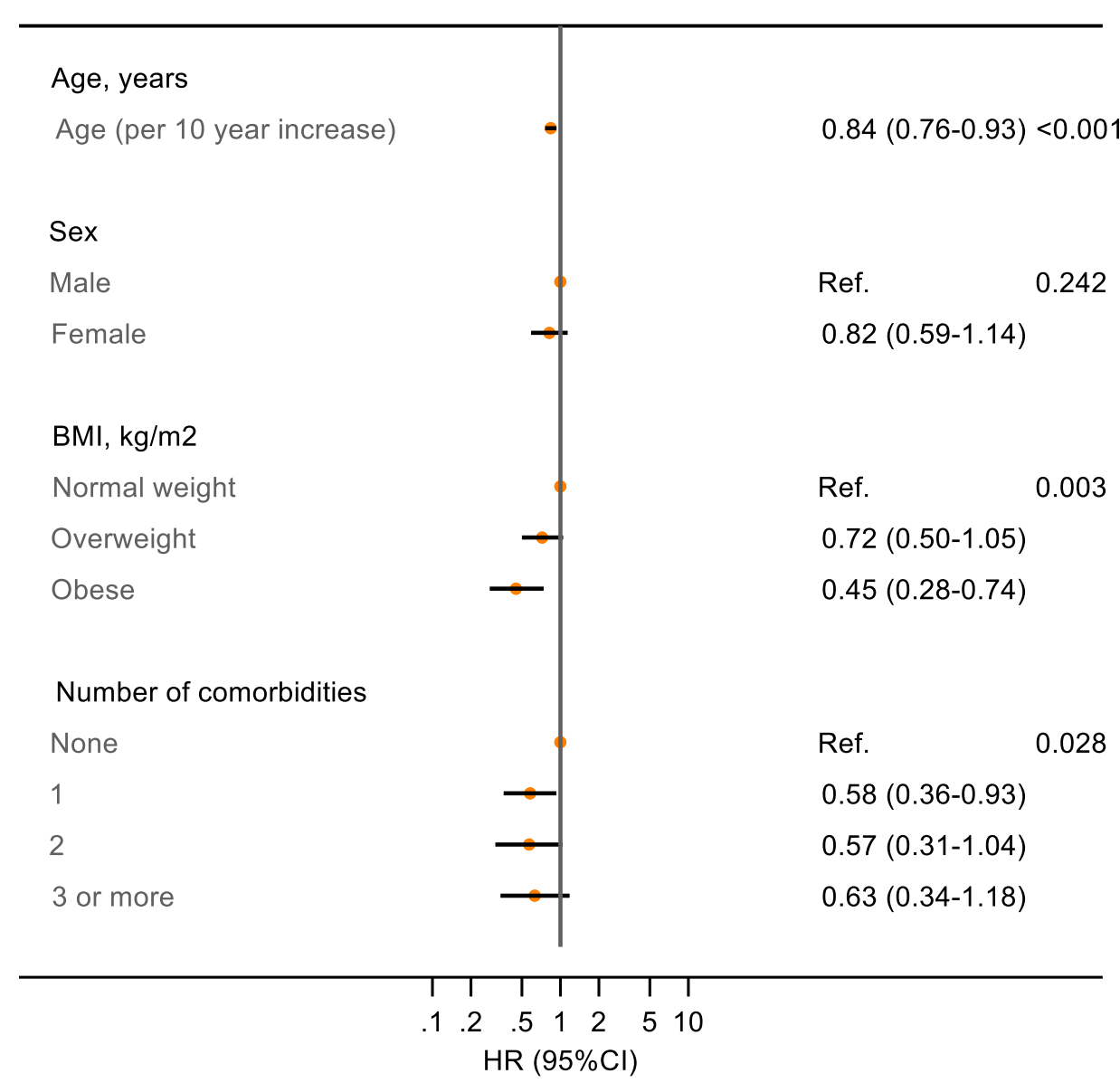

\section{Multivariable Model}

Determinants at illness onset aHR (95\% Cl) P-value

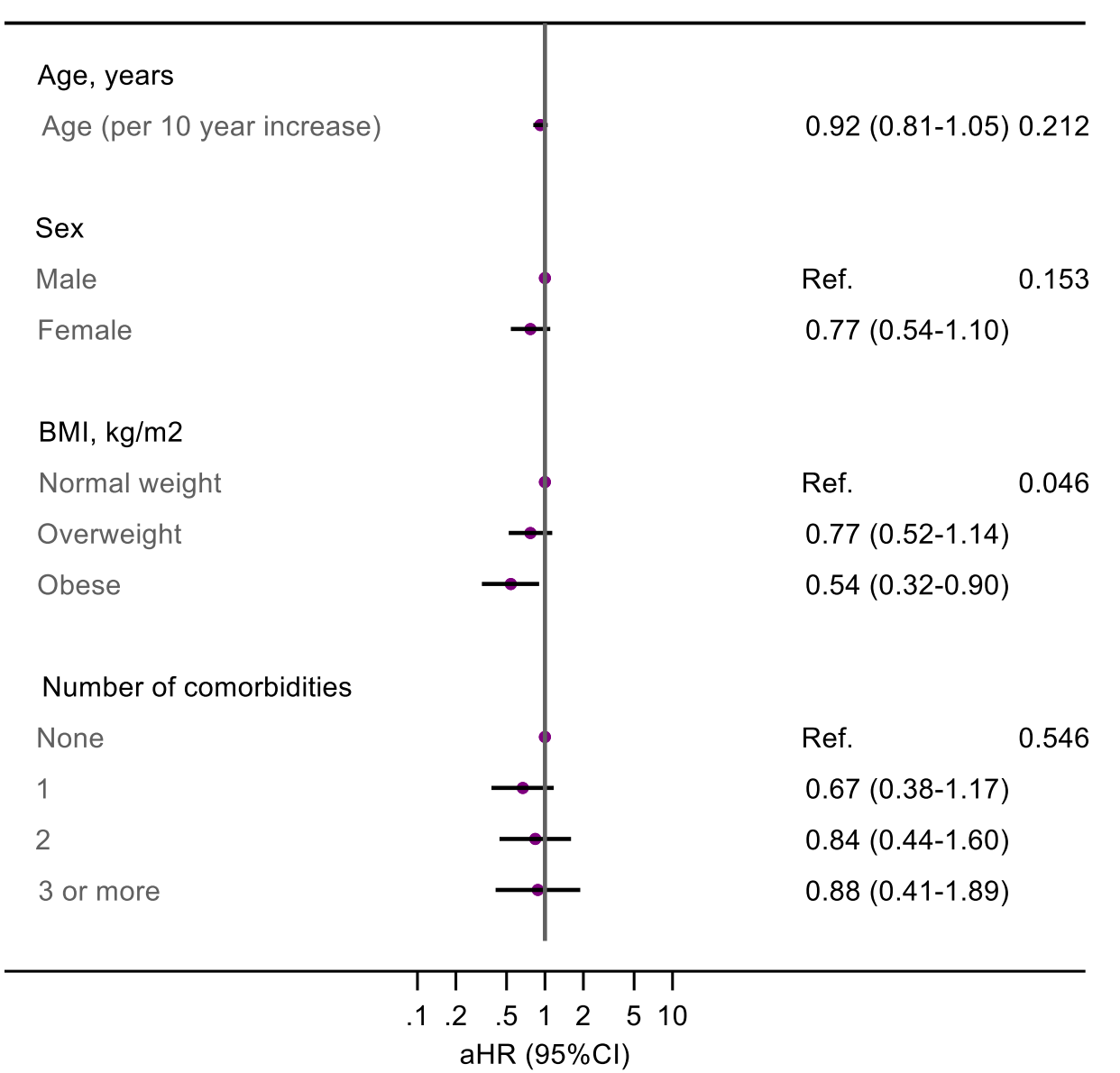

Comorbidities counted are those listed by the WHO as being associated with a higher risk of developing severe or critical COVID-19[11]. Body mass index (BMI) categorised in $\mathrm{kg} / \mathrm{m}^{2}$ as: $<25$, underweight or normal weight; 25 up to 30 , overweight; $>30$, obese. P-value calculated using likelihood ratio test. 